\title{
A NEW APPROACH FOR THE EXTRACTION OF ORGANIC COMPOUNDS FROM DIFFERENT TYPES OF CONTAMINATED WATERS AND SEWAGE SLUDGE
}

\author{
Andrei Niculae
}

National Research and Development Institute for Industrial Ecology-ECOIND, DrumulPoduDambovitei Street, 71-73, Sector 6, Bucharest, e-mail address: vasileiancu10@gmail.com, Romania

\begin{abstract}
Liquid-liquid extraction LLE, is one of the oldest separation techniques, with most used applications in analytical chemistry especially for contaminated waters. LLE extraction involves different distribution of chemical species between two immiscible liquid phases, depending on their physical-chemical properties. Other different extraction techniques used to remove organic compounds from contaminated water and sewage sludge can be enumerated: the following techniques: continuous liquid-liquid extraction, solid-liquid extraction, solid phase microextraction, accelerated solvent extraction, ultrasonic extraction and some correlated techniques. A new extraction technique partially based on the principle of continuous extraction with recirculation of the sample through a layer of solvent or mixture of solvents was developed in our analytical laboratory. The extraction method was verified by comparison with three classical techniques: liquid-liquid extraction, solid-liquid and ultrasonic extraction. The results have demonstrated the performance of this new extraction technique consisting in reduced time and costs for sample preparation and especially increased efficiency for extraction of organic compounds from sewage sludge.
\end{abstract}

Keywords: LLE, soxhlet, continuous extraction, sewage sludge extraction, ultrasonic extraction

\section{Introduction}

In current laboratory analyses, the LLE 1-2 is still the most used technique for water matrices due to the short time procedure. The main disadvantage of LLE is the low reproducibility. Solid phase extraction (SPE) 3 , is another common extraction technique that has the main advantage to be used as an extraction procedure and also as a cleanup technique due to its high selectivity. The SPE imply more expensive costs than LLE primarily due to the single use cartridges and the procedure time. Other laboratory techniques used for water matrices require special equipments and expensive consumable, one of these is the solid phase microextraction(SPME) and similar microwave assisted solvent extraction (MASE)5. There are some special combined extraction techniques such, (DLLME)-dispersive liquid-liquid microextraction, (MSPE) - magnetic solid-phase extraction, SBSE6 -stir-bar sorptive extraction, HF-LPME7 -hollow fiber liquid phase microextraction.For sewage sludge extraction there are few main techniques: the ultrasonic extraction8,9 and accelerated solvent extraction. The ultrasonic extraction is fast, high productive and doesn't need 
dry samples. The main disadvantage for this technique is the degradation and compositional changes of the sample. Another used technique is the Soxhlet10 extraction that require the sample to be dry. This technique is highly efficient and selective. The drawbacks of this type of extraction is the consuming time process, the high volume of solvents used and the hazard of boiling solvents. Other extraction techniques for sewage sludge is the accelerated solvent extraction (ASE)11,that it is rarely used due to the high costs of the equipment. ASE is a rapid, efficient and high productive technique. The main disadvantage of this technique is the lack of selectivity and the dilution effect. For this reason ASE is coupled with additional cleanup techniques, such as SPE and largevolume injection (LVI). For laboratories with high volume of samples, is necessary to use a rapid and efficient extraction technique. Generally, for water matrices the most used techniques is automated SPE, used also for the cleanup stages. Instead, for sewage sludge there are no generic extraction techniques used. The main reason is the difficulty in the samples preparation; first step is the homogenization stage and then the cool drying process that takes at least 24 hours. After drying, the sample can be subjected to different less time consuming techniques such as ultrasonic extraction, ASE or other techniques used also for soil samples. A non-drying technique for sewage sludge extraction is solid-liquid extraction (SLE)12, were the sample is treated as it is, being considered homogenous. The aim of this paper is to present a new approach for the liquid-liquid separation technique partially based on classical continuous LLE (liquid-liquid extraction) and also on Soxhlet technique. In laboratory practice, the extraction of organic compounds from matrices like waste water and sewage sludge imply time consuming procedures, expensive consumables and a considerable volume of reagents.

\section{Materials and Methods}

The high volume of water samples and also the difficulty to sewage sludge extraction let us to develop an system which can offer fast and efficient extraction. To increase the laboratory capabilities for the water samples analysis and to solve the problem of sewage sludge extraction, we have started from two extraction systems. The first model was the continuous LLE which offer good efficiency through the repeated extraction cycles. The problem with this separation technique is the operation temperaturethat may affect the sample, leading to matrix and/or analyte degradation. Another similar extraction system is the Soxhlet equipment where the solid sample is extracted through repeated "washing" cycles. Cold Soxhlet extraction solve the problem of the solvent temperature but imply another impediment, the extraction time.Itwas started from the efficiency through the repeated "washing" cycles of the both extraction techniques.

The main question was how to recirculate the solvent without involvement of temperature. In both extraction techniques, the sample is stationary, a fact that can imply a difficult extraction in the all mass of the sample especially for solid samples and sewage sludge. Watching the bypass sidearm of the extraction tube from a Soxhlet system let us to rethink the solvent recirculation. It began to think to the possibility to recirculate the sample in a system where the solvent is stationary. After many different trials, we found the optimum solution. The final concept,recirculate the sample, water or sewage sludge, through a nitrogen low 
pressure stream. The system was optimized, to have a long solvent column through which the sample is recirculated.The extraction system in presented in figure 1.



Fig. 1. Extraction system

High-purity solvents were used. Acetone picograde, n-Hexane picograde, Toluene picograde and n-Nonanepicograde, were purchased from LGC Standards. Analytical standards such as organochlorine pesticide mixture $(\mathrm{OCP})$, chlorobenzene mixture (CBz), polychlorobiphenyl congers mixture (PCB) and alkane standard mixture (C10-C40), were purchased from SigmaAldrich. Internal standards such 1-bromo-2-nitrobenzene, PCB30 and PCB 209 were also purchased from Sigma-Aldrich. Stock solution of OCP were prepared in acetone at $1.0 \mu \mathrm{g} / \mathrm{mL}$ each component. Stock solution of $\mathrm{CBz}$ were prepared in acetone at $0.5 \mu \mathrm{g} / \mathrm{mL}$ each component. Stock solution of PCBs congeners were prepared in acetone at $1.0 \mu \mathrm{g} / \mathrm{mL}$ each conger. Stock solution of internal standards 1-bromo-2-nitrobenzene, PCB30 and PCBs 209 were also prepared in acetone at $1.0 \mu \mathrm{g} / \mathrm{mL}, 1.0 \mu \mathrm{g} / \mathrm{mL}$ respectively $1.4 \mu \mathrm{g} / \mathrm{mL}$. All stock solutions were preserved at $4 \mathrm{C}$ in $20 \mathrm{~mL}$ gastight vials. For concentration of extracts we used a rotary evaporator Laborota 4000 from Heidolph. A nitrogen generator was used, V350 Alliance from F-GDS.Gas chromatography separations were carried out with Agilent Technologies equipments, 7890 A gas chromatograph with $\mu E C D$ detector and $6890 \mathrm{~N}$ gas chromatographwith FID detector. The separations were performed on a capillary column from Phenomenex, ZB-5HT of $60 \mathrm{~m}, 0.25 \mathrm{~mm}$ I.D and $0.25 \mu \mathrm{m}$ thickness of stationary phase and the second column was ZB-1HT of $30 \mathrm{~m}, 0.25$ I.D. and $0.25 \mu \mathrm{m}$ thickness of stationary phase. The instrumental methods was optimized for separation of OCP, CBz and PCBs using internal standards and another method for alkane mixture C10C40 without internal standard. The recovery standard was PCB30.

\section{Results and Discussion}

We carried out operating tests to adjust the parameters of the extractor and to calculate the accuracy and extraction yield. For the optimization of parameters, extraction was led with samples of water and sewage sludge, samples 
contaminated with $\mathrm{OCP}, \mathrm{PCBs}, \mathrm{CBz}$ and $\mathrm{C} 10-\mathrm{C} 40$. The samples were extracted at different flow rates and recirculation times. It was use as a extraction solvent a mixture of $n$-hexane: toluene $(80: 20 \mathrm{v} / \mathrm{v})$. First experiments were carried out for contaminated surface water. The surface water was

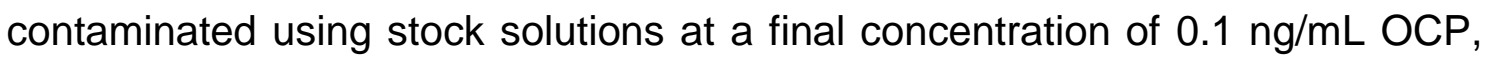
$\mathrm{CBz}$ and PCB and $100 \mathrm{ng} / \mathrm{mL}$ for C10-C40. Thenitrogen flow rate of nitrogen used was between $0.5 \mathrm{~mL} / \mathrm{min}$ and $5 \mathrm{~mL} / \mathrm{min}$. with increments of $0.5 \mathrm{~mL} / \mathrm{min}$. The extraction time was chosen at 20 minutes. The extract was concentrated at rotary evaporator using $0.5 \mathrm{~mL} \mathrm{n}$-nonane as a keeper.After concentration till 0.5 $\mathrm{mL}$ final volume, the extract was analyzed by gas chromatograph. The yield of OCP was calculated as an average using one compound from every pesticide class from the mixture. For calculation were used the next compounds: $\mathrm{g}-\mathrm{HCH}$ ,aldrin, 4,4-DDE, endosulfan and heptachlor. It was also calculated the accuracy of the results as procentual average of the concentration result vs. real value. The obtained results are presented in Table 1 and Figure2. For OCP experiment it was deducted the optimal flow rate of $1.5 \mathrm{~mL} / \mathrm{min}$ at $20 \mathrm{~min}$. extraction time.

Table 1. Results obtained for surface water contaminated with OCP

\begin{tabular}{|c|c|c|c|c|c|c|c|}
\hline $\begin{array}{c}\text { Sample } \\
\text { type }\end{array}$ & $\begin{array}{c}\text { Flow rate } \\
\mathrm{N}_{2} \\
(\mathrm{~mL} / \mathrm{min})\end{array}$ & $\begin{array}{l}\text { Extraction } \\
\text { time (min) }\end{array}$ & $\begin{array}{c}\text { Extraction } \\
\text { solvent } \\
\text { volume } \\
(\mathrm{mL}) \\
\end{array}$ & $\begin{array}{c}\text { Sample } \\
\text { volume } \\
(\mathrm{mL})\end{array}$ & Analytes & $\begin{array}{c}\text { Average } \\
\text { accuracy } \\
\text { (\%) }\end{array}$ & $\begin{array}{c}\text { Average } \\
\text { yield } \\
(\%)\end{array}$ \\
\hline \multirow{9}{*}{ 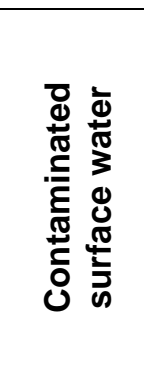 } & 0.5 & 20 & 30 & 600 & OCP & 92.5 & 76 \\
\hline & 1.0 & 20 & 30 & 600 & OCP & 91.5 & 83.5 \\
\hline & 1.5 & 20 & 30 & 600 & OCP & 93.0 & 89.5 \\
\hline & 2.0 & 20 & 30 & 600 & OCP & 94.5 & 80.5 \\
\hline & 2.5 & 20 & 30 & 600 & OCP & 92.5 & 82 \\
\hline & 3.0 & 20 & 30 & 600 & OCP & 93.0 & 81 \\
\hline & 3.5 & 20 & 30 & 600 & OCP & 92.0 & 84 \\
\hline & 4.5 & 20 & 30 & 600 & $\mathrm{OCP}$ & 91.5 & 74 \\
\hline & 5.0 & 20 & 30 & 600 & OCP & 92.0 & 66.5 \\
\hline
\end{tabular}

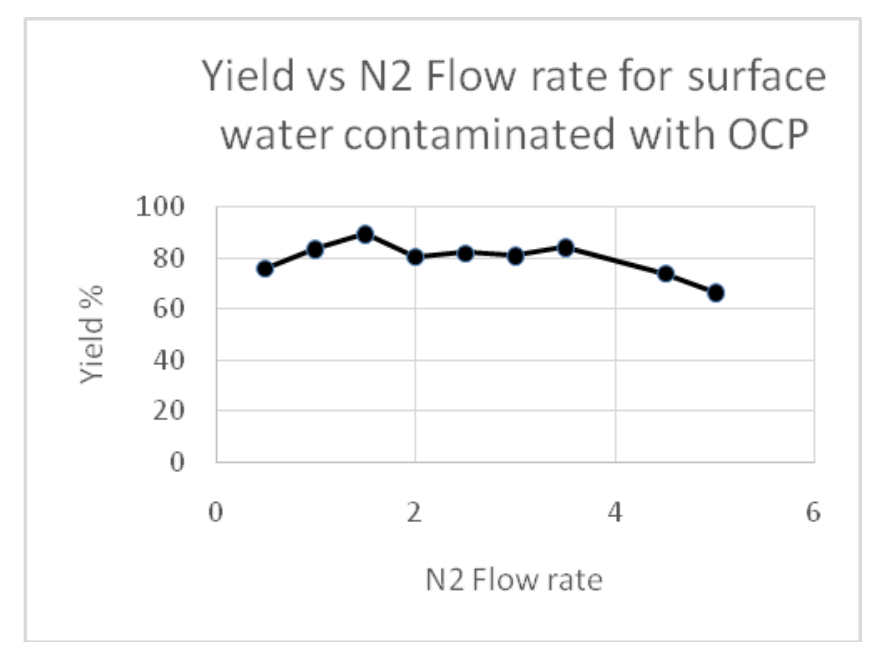

Figure2. Graphic representation of yields vs. N2 flow rate.

The next experiment was carried out for PCB congeners in the same manner as for the OCP contaminated water. The obtained results are presented in Table 2 
and Figure3. The optimal flow rate for PCB congers was determinated to be 1.0 $\mathrm{mL} / \mathrm{min}$.

Table 2. Results obtained for surface water contaminated with PCB congeners.

\begin{tabular}{|c|c|c|c|c|c|c|c|}
\hline $\begin{array}{c}\text { Sample } \\
\text { type }\end{array}$ & $\begin{array}{c}\text { Flow rate } \\
\mathrm{N}_{2} \\
(\mathrm{~mL} / \mathrm{min})\end{array}$ & $\begin{array}{l}\text { Extraction } \\
\text { time (min) }\end{array}$ & $\begin{array}{c}\text { Extraction } \\
\text { solvent } \\
\text { volume } \\
(\mathrm{mL})\end{array}$ & $\begin{array}{c}\text { Sample } \\
\text { volume } \\
(\mathrm{mL})\end{array}$ & Analytes & $\begin{array}{l}\text { Average } \\
\text { accuracy } \\
(\%)\end{array}$ & $\begin{array}{c}\text { Average } \\
\text { yield } \\
(\%)\end{array}$ \\
\hline \multirow{9}{*}{ 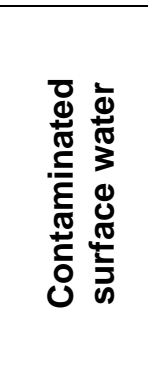 } & 0.5 & 20 & 30 & 600 & PCB & 94.0 & 89.0 \\
\hline & 1.0 & 20 & 30 & 600 & PCB & 94.5 & 94.5 \\
\hline & 1.5 & 20 & 30 & 600 & PCB & 94.5 & 92.5 \\
\hline & 2.0 & 20 & 30 & 600 & PCB & 95.0 & 92.0 \\
\hline & 2.5 & 20 & 30 & 600 & PCB & 94.0 & 92.0 \\
\hline & 3.0 & 20 & 30 & 600 & PCB & 93.5 & 90.5 \\
\hline & 3.5 & 20 & 30 & 600 & PCB & 94.0 & 89.0 \\
\hline & 4.5 & 20 & 30 & 600 & PCB & 93.5 & 89.0 \\
\hline & 5.0 & 20 & 30 & 600 & PCB & 94.0 & 92.0 \\
\hline
\end{tabular}

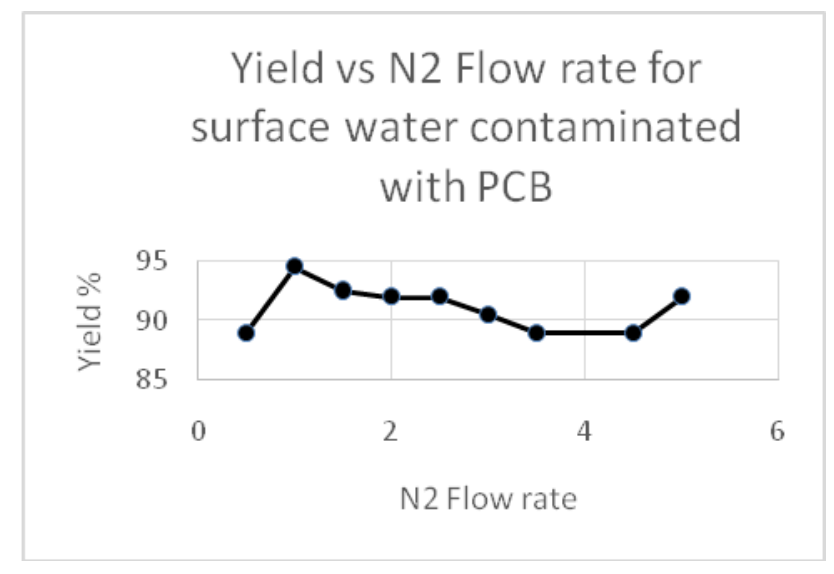

Figure3.Graphic representation of yields vs. N2 flow rate.

The experiments for $\mathrm{CBz}$ were carried out in the same manner and obtained results presented in Table 3 and Figure4, show a optimum flow rate at 1.5 $\mathrm{mL} / \mathrm{min}$.

Table 3. Results obtained for surface water contaminated with $\mathrm{CBz}$.

\begin{tabular}{|c|c|c|c|c|c|c|c|}
\hline $\begin{array}{c}\text { Sample } \\
\text { type }\end{array}$ & $\begin{array}{c}\text { Flow rate } \\
\mathrm{N}_{2} \\
(\mathrm{~mL} / \mathrm{min})\end{array}$ & $\begin{array}{l}\text { Extraction } \\
\text { time (min) }\end{array}$ & $\begin{array}{c}\text { Extraction } \\
\text { solvent } \\
\text { volume } \\
(\mathrm{mL})\end{array}$ & $\begin{array}{c}\text { Sample } \\
\text { volume } \\
\text { (mL) }\end{array}$ & Analytes & $\begin{array}{l}\text { Average } \\
\text { accuracy } \\
\text { (\%) }\end{array}$ & $\begin{array}{c}\text { Average } \\
\text { yield } \\
(\%)\end{array}$ \\
\hline \multirow{9}{*}{ 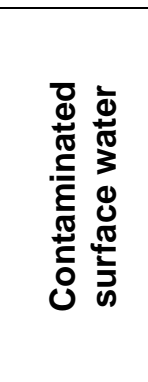 } & 0.5 & 20 & 30 & 600 & $\mathrm{CBz}$ & 94.5 & 78.5 \\
\hline & 1.0 & 20 & 30 & 600 & CBz & 93.5 & 84.5 \\
\hline & 1.5 & 20 & 30 & 600 & $\mathrm{CBz}$ & 94.5 & 85.5 \\
\hline & 2.0 & 20 & 30 & 600 & $\mathrm{CBz}$ & 92.0 & 84.5 \\
\hline & 2.5 & 20 & 30 & 600 & $\mathrm{CBz}$ & 93.5 & 80.5 \\
\hline & 3.0 & 20 & 30 & 600 & $\mathrm{CBz}$ & 89.5 & 80.5 \\
\hline & 3.5 & 20 & 30 & 600 & CBz & 91.5 & 80 \\
\hline & 4.5 & 20 & 30 & 600 & $\mathrm{CBz}$ & 92.0 & 81 \\
\hline & 5.0 & 20 & 30 & 600 & $\mathrm{CBz}$ & 91.0 & 80 \\
\hline
\end{tabular}




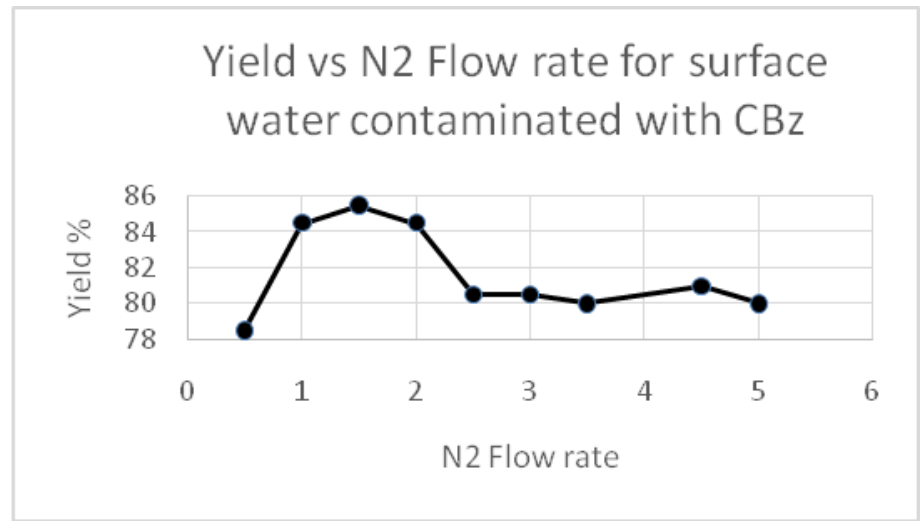

Figure 4.Graphic representation of yields vs. N2 flow rate.

The experiments for $\mathrm{C} 10-\mathrm{C} 40$ were carried out in the same way as for previous compounds. The results presented in Table 4 and Figure5 show that optimum flow rate has to be between 1.0 and $2.0 \mathrm{~mL} / \mathrm{min}$.

Table 4. Results obtained for surface water contaminated with C10-C40 .

\begin{tabular}{|c|c|c|c|c|c|c|c|}
\hline $\begin{array}{c}\text { Sample } \\
\text { type }\end{array}$ & $\begin{array}{c}\text { Flow rate } \\
\mathrm{N}_{2} \\
(\mathrm{~mL} / \mathrm{min})\end{array}$ & $\begin{array}{l}\text { Extraction } \\
\text { time (min) }\end{array}$ & $\begin{array}{c}\text { Extraction } \\
\text { solvent } \\
\text { volume } \\
(\mathrm{mL})\end{array}$ & $\begin{array}{c}\text { Sample } \\
\text { volume } \\
(\mathrm{mL})\end{array}$ & Analytes & $\begin{array}{l}\text { Average } \\
\text { accuracy } \\
\text { (\%) }\end{array}$ & $\begin{array}{c}\text { Average } \\
\text { yield } \\
(\%)\end{array}$ \\
\hline \multirow{9}{*}{  } & 0.5 & 20 & 30 & 600 & C10-C40 & 91.0 & 88.5 \\
\hline & 1.0 & 20 & 30 & 600 & C10-C40 & 89.0 & 92.0 \\
\hline & 1.5 & 20 & 30 & 600 & C10-C40 & 91.5 & 92.5 \\
\hline & 2.0 & 20 & 30 & 600 & C10-C40 & 90.0 & 92.5 \\
\hline & 2.5 & 20 & 30 & 600 & C10-C40 & 89.0 & 91.0 \\
\hline & 3.0 & 20 & 30 & 600 & C10-C40 & 89.5 & 91.0 \\
\hline & 3.5 & 20 & 30 & 600 & C10-C40 & 87.0 & 90.0 \\
\hline & 4.5 & 20 & 30 & 600 & C10-C40 & 88.5 & 88.5 \\
\hline & 5.0 & 20 & 30 & 600 & C10-C40 & 89.0 & 87.0 \\
\hline
\end{tabular}

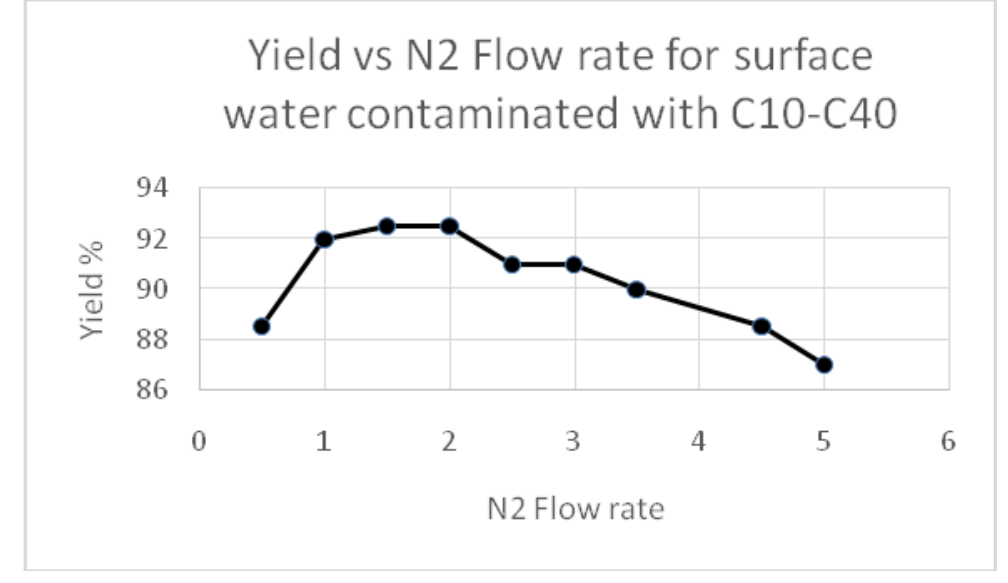

Figure5.Graphic representation of yields vs. N2 flow rate.

For sewage sludge experiments, the samples were contaminated with the same compounds as for surface water, at 100 times higher concentrations compared 
with contamination of surface water. For $\mathrm{OCP}, \mathrm{CBz}$ and $\mathrm{PCB}$ the sewage sludge was contaminated at $10 \mathrm{ng} / \mathrm{mL}$ and $10 \mathrm{ug} / \mathrm{mL}$ for C10-C40. The extraction experiments were carried out at a flow rate of $\mathrm{N} 2$ between 0.5 $\mathrm{mL} / \mathrm{min}$. and $2 \mathrm{~mL} / \mathrm{min}$ with the same extraction time of 20 minutes. The results are summarized in Table 5 and Figure 6 for all the compound classes.

Table 5. Results obtained for contaminated sewage sludge.

\begin{tabular}{|c|c|c|c|c|c|c|c|}
\hline $\begin{array}{c}\text { Sample } \\
\text { type }\end{array}$ & $\begin{array}{c}\text { Flow rate } \\
\mathrm{N}_{2} \\
(\mathrm{~mL} / \mathrm{min})\end{array}$ & $\begin{array}{l}\text { Extraction } \\
\text { time (min) }\end{array}$ & $\begin{array}{c}\text { Extraction } \\
\text { solvent } \\
\text { volume } \\
(\mathrm{mL})\end{array}$ & $\begin{array}{c}\text { Sample } \\
\text { volume } \\
\text { (mL) }\end{array}$ & Analytes & $\begin{array}{c}\text { Average } \\
\text { accuracy } \\
(\%)\end{array}$ & $\begin{array}{c}\text { Average } \\
\text { yield } \\
(\%)\end{array}$ \\
\hline \multirow{16}{*}{  } & 0.5 & 20 & 30 & 600 & OCP & 84.5 & 78.0 \\
\hline & 1.0 & 20 & 30 & 600 & $\mathrm{OCP}$ & 85.5 & 82.5 \\
\hline & 1.5 & 20 & 30 & 600 & OCP & 85.0 & 84.5 \\
\hline & 2.0 & 20 & 30 & 600 & $\mathrm{OCP}$ & 84.5 & 84.0 \\
\hline & 0.5 & 20 & 30 & 600 & PCB & 76.5 & 74.5 \\
\hline & 1.0 & 20 & 30 & 600 & PCB & 77.0 & 75.5 \\
\hline & 1.5 & 20 & 30 & 600 & PCB & 77.0 & 75.0 \\
\hline & 2.0 & 20 & 30 & 600 & PCB & 77.0 & 75.0 \\
\hline & 0.5 & 20 & 30 & 600 & $\mathrm{CBz}$ & 81.0 & 74.0 \\
\hline & 1.0 & 20 & 30 & 600 & $\mathrm{CBz}$ & 82.0 & 74.0 \\
\hline & 1.5 & 20 & 30 & 600 & $\mathrm{CBz}$ & 82.5 & 76.0 \\
\hline & 2.0 & 20 & 30 & 600 & $\mathrm{CBz}$ & 82.0 & 76.0 \\
\hline & 0.5 & 20 & 30 & 600 & C10-C40 & 87.0 & 91.0 \\
\hline & 1.0 & 20 & 30 & 600 & C10-C40 & 88.0 & 91.0 \\
\hline & 1.5 & 20 & 30 & 600 & C10-C40 & 88.0 & 93.5 \\
\hline & 2.0 & 20 & 30 & 600 & C10-C40 & 87.0 & 91.5 \\
\hline
\end{tabular}

\section{Yields vs N2 flow rates}

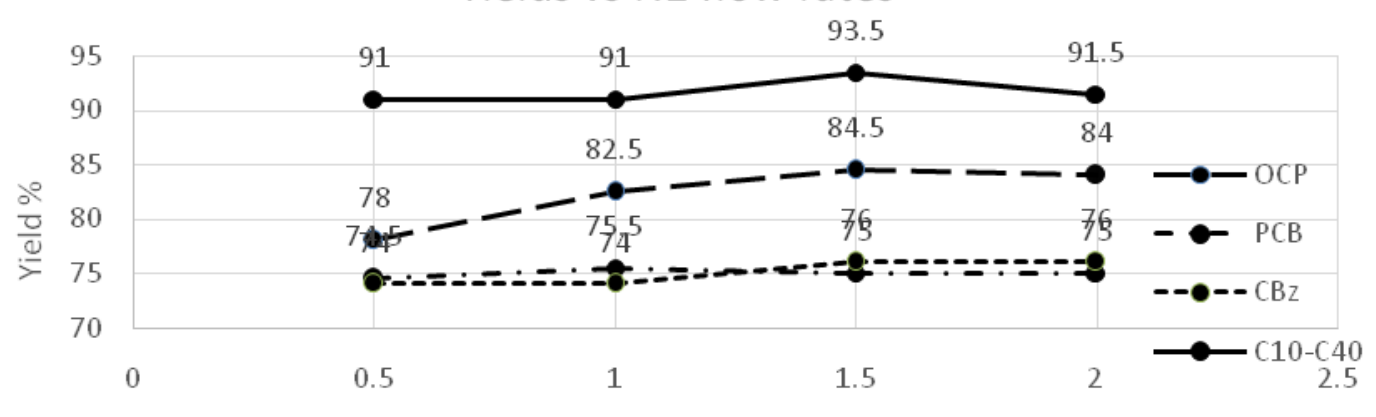

Flow rate

Figure6. Graphic representation of yields vs. N2 flow rate. 


\section{CONCLUSIONS}

A new extraction technique was developed and optimized for several semivolatile organic compounds. The results of the conducted experiments showed that the extraction technique is fast, accurate, efficient and cheap. The technique has as a necessity, a cleanup stage. The recirculation of sample in the extraction solvent column can be better optimized to increase the contact surface between the sample and extraction fluid. Future automatization can bring this kind of extractor as common laboratory equipment.

\section{REFERENCES}

1. A.NEZIRI, I.MALOLLARI, Persistent Organic Pollutants in the Buna river basin ground waters, J Envir. ProtEcol 15, No 2, 405-411 (2014).

2. M.CULEA, A.IORDACHE, Trihalomethanes Analysis in Drinking Water, J Envir. ProtEcol10, No 2, 342-350 (2009).

3. V.I.IANCU, J.PETRE, L.CRUCERU, Determination of some organophosphorus insecticides and urea herbicides from water by HPLC, J Envir. ProtEcol No 12, 833-840 (2011)

4. A.J.HANDLEY, E.R.ADLARD, Gas Chromatographic Techniques and Applications, 23-26 (2001).

5. M.KAMANKESH, A.MOHAMMADI, Rapid determination of polycyclic aromatic hydrocarbons in grilledmeat using microwave-assisted extraction and dispersive liquid-liquid microextraction coupled to gas chromatography-mass spectrometry, M Sci 103, 61-67 (2015).

6. M.ROLDAN-PIJUAN, R.LUCENA, Stir fabric phase sorptive extraction for the determination of triazineherbicides in environmental waters by liquid chromatography, JChrom, 1376, 35-45 (2015).

7. J.A.OCANA-GONZALES, M.VILLAR-NAVARRO, M.RAMOS-PAYAN, New developments in the extraction and determination of parabens in cosmetics and environmental samples. A review, Anal ChimActa, 858, 1-15 (2015).

8. C.M.TANG, Q.X.HUANG, Multiresidue determination of sulfonamides, Macrolides, Trimethoprim and Chloramphenicol in sewage sludge and sediment using ultrasonic extraction coupled with solid phase extraction and liquid chromatography-tandem mass spectrometry, Chin J of Anal Chem, 37(8), 11191124 (2009).

9. S.BARAN, P.OLESZCZUK, Chromatographic determination of polycyclic aromatic hydrocarbons $(\mathrm{PAH})$ in sewage sludge, Soil and Sewage-Amended soils, Polish JEniron Stud, 11(6), 609-615(2002).

10. M.S.RAHMAN, A.B.PAYA-PEREZ, Chlorobiphenyls in sewage sludge;coparison of extraction methods, Fresenius J.Chem., 360, 556-563 (1998).

11. E.M.GOLET, A.STREHLER, Determination of fluoroquinolone antibacterial agents in sewage sludge and sludge-treated soil using accelerated solvent extraction followed by solid-phase extraction, Anal.Chem., 74(21), 5455-5462 (2002).

12. G.P.PINHO, F.O.SILVERIO, Determination of Chlorobenzene in sewage sludge by solid-liquid extraction with purification at low temperature and gas chromatography mass spectrometry, J.Braz.Chem.Soc., No 7, 25, 1292-1301 (2014) 